\title{
Effect of the tumbling process and kappa-carrageenan usage on the quality characteristics of meat loaf')
}

\author{
NIHAT TELLI, ARIFE EZGI TELLI*, YUSUF BIÇER*, MUHAMMET ALI CEBIRBAY**, \\ KEMAL KAAN TEKINŞEN*, ISMAIL ERIM KÖSEOĞLU***, AHMET GÜNER*
}

\begin{abstract}
Department of Food Technology, Vocational School of Technical Sciences, Konya Technical University, Konya, Turkey
*Department of Food Hygiene and Technology, Faculty of Veterinary Medicine, Selcuk University, Konya, Turkey **Department of Nutrition and Dietetics, Faculty of Health Sciences, Selcuk University, Konya, Turkey

${ }^{* * *}$ General Directory of Meat and Milk Board, Ankara, Turkey
\end{abstract}

Telli N., Telli A. E., Biçer Y., Cebirbay M. A., Tekinşen K. K., Köseoğlu İ. E., Güner A. Effect of the tumbling process and kappa-carrageenan usage on the quality characteristics of meat loaf

Summary

In this study the authors aimed to determine the effects of the tumbling process and carrageenan usage on the physicochemical, microbiological and sensory properties of meat loaves, which are uncommon in Turkey and only produced at a sub-industrial level. The meat loaves were produced from beef (rib and chuck regions) and layer hen meat and partitioned equally into three groups. The first group served as a control group, whereas the second and third groups were processed by tumbling for 1 and $2 \mathrm{~h}$, respectively. The tumbling programme involved 20 millibar pressure, with $3 \mathrm{~min}$ of operation and $1 \mathrm{~min}$ of stoppage. After tumbling, each group was divided into two equal parts, followed by the addition of $1 \%$ carrageenan to one part of each. This production was repeated, and the meat loaves were stored at $4^{\circ} \mathrm{C}$. Physicochemical, microbiological and sensory analyses of the final products were performed on the $0^{\text {th }}, 3^{\text {rd }}, 7^{\text {th }}, 12^{\text {th }}$ and $15^{\text {th }}$ day of storage for assessing the product quality. The utilisation of carrageenan increased the beef and chicken meat loaves by $0.69 \%$ and $1.85 \%$, respectively. The carrageenan reduced cooking loss by an average of $5 \%$ relative to the control group. The cutting and sensory properties of the groups produced by both tumbling and the addition of carrageenan exhibit higher scores than the other groups $(\mathrm{P}<0.05)$. The average of the $\mathrm{pH}$, aw, salt \%, dry matter\%, ash\% and fat $\%$ in the beef meat loaves are $6.26,0.938,0.988,31.52,2.30$ and 4.64 , respectively, whereas corresponding values for chicken meat loaves are $6.26,0.927,1.23,35.80,2.18$ and 7.38 , respectively for the control groups. Yeast-mould growth was absent in all samples, containing 2.90-6.05 $\log _{10} \mathrm{CFU} / \mathrm{g} \mathrm{TMAB}, 2.00-4.27 \log _{10} \mathrm{CFU} / \mathrm{g}$ Micrococcus-Staphylococcus and 0-3.62 $\log _{10} \mathrm{CFU} / \mathrm{g}$ Enterobacteriaceae.

Keywords: meat loaf, kappa-carrageenan, tumbling

In recent years, the consumer demand for ready-toeat meat products is rising because of socio-economic factors. This has triggered innovations including the production of restructured meat products in the meat industry $(10,21)$. Restructured meat is a product transformed into a similar or different form by ensuring the integrity of the chopped meat (21). It is a technological approach for recreating low-value meat preparations $(5,18)$ and constitutes added value for the meat industry $(10,26)$.

Meat loaf is a restructured product with a high nutritional value, allowing the usage of trimmed meat

1) This study was supported by the Selçuk University Scientific Research Projects Coordination Unit with the project number of 10401123. A part of this study was presented in $7^{\text {th }}$ Veterinary Food Hygiene Congress in Kuşadası, Aydın/Turkey. and meat by-products. Specific and nonspecific meat loaves prepared by varied formulations are available (36). Their production steps are often similar (1), and the raw materials are generally low economic value meat, fat and meat by-products. Trimmed meat and meat by-products produce a high connecting tissue, low tenderness and juiciness. However, the associated cooking loss adversely affects the product quality $(17,35)$.

Tumbling, which involves the combined use of impact and friction energies $(45,48)$, is an effective mechanical process for producing tender and juicy meat (25), characterised by homogenous penetration of curing agents $(24,40)$. The main purpose of the process is to enable sufficient extraction of salt-soluble 
proteins for improving the tenderness, juiciness and slicing properties (21). Because of its hydrocolloidal structure, carrageenan is utilised for gel formation, water retention and imparting desired textural properties for meat products $(29,34)$. Carrageenans are sulfated polymers of galactose and anhydrogalactose extracted from red seaweeds. Although the three main types of carrageenans are iota, kappa and lambda, the kappa type is that commonly used in food technology $(4,8,12,37)$.

In this study, the effects of tumbling and adding carrageenan on the quality characteristics of meat loaves are examined.

\section{Material and methods}

Production of meat loaves and experimental groups. In producing the meat loaves, trimmed ribs from beef meat and layer chicken ribs and forearms meat were used as the raw materials. The meat (beef and layer hen meat), oil, spices and other additives used as raw materials were obtained from retail markets in Konya, Turkey. The production occurred at two different times, forming experimental production groups (Tab. 1). The loaf dough compositions were determined as presented in Table 2 . The tumbling programme involved 20 millibar pressure, with 3 min of operation and 1 min of stoppage in tumbling machine (Scharfen Tumbler HR2530).

The prepared loaf dough was stored stainless steel containers measuring $11 \times 8.5 \times 3.5 \mathrm{~cm}$. After covering the loaf dough with an aluminium lid, the product was baked in an air-conditioning furnace (Fessmann/Microprocessor MC-3) until the core temperature reached $75^{\circ} \mathrm{C}$. After baking, $3 \mathrm{~mm}$ slices were produced, vacuum packed (Kramer + Grebe Compack Tabletop Packager) and stored at $4^{\circ} \mathrm{C}$. Physicochemical, microbiological and sensory analyses of the final products were performed on the $0^{\text {th }}, 3^{\text {rd }}, 7^{\text {th }}, 12^{\text {th }}$ and $15^{\text {th }}$ day of storage for assessing the product quality.

Physicochemical analysis. The yield (\%) was calculated by weighing the samples before heat treatment and before packing after cooling as previously described $(19,56)$. Following the cooking stage, all samples were cooled to $50^{\circ} \mathrm{C}$ and then weighed by removing the excess liquid. The cooking loss (\%) for the samples were calculated considering the weights before heat treatment as detailed in the past (1). Meat loaf samples cutting properties were evaluated as good or bad according to whether the knife cutting was clean, sticky or crumby, with details reported previously (35). The $\mathrm{pH}$ of the samples was determined by a digital pH metre (InoLab pH 720 model, WTW, GmbH), whereas the $\mathrm{a}_{\mathrm{w}}$ was determined by a water activity device (Novasina LabSwift-aw). Dry matter analyses were performed using an AND MX-50 moisture analyser, whereas the salt contents were determined according to a modified Mohr method (6) and the ash content was measured according to the TS 1746 standard established by the Turkish Standards Institute (50). Fat content was also determined according to the procedure described by Pearson and Tauber (39).

Microbiological analysis. About $10 \mathrm{~g}$ of samples were weighed into sterile specimen bags and homogenised with $90 \mathrm{ml}$ of $1 / 4$ strength Ringer (Oxoid BR0052) solution in
Tab. 1. Produced experimental groups

\begin{tabular}{|c|c|c|c|}
\hline Raw material & $\begin{array}{c}\text { Experimental } \\
\text { Groups }\end{array}$ & Tumbling & $\begin{array}{c}\text { Carrageenan } \\
(\mathbf{1} \%)\end{array}$ \\
\hline \multirow{5}{*}{ Beef meat loaf } & I & - & + \\
& II & - & - \\
& III & $1 \mathrm{~h}$ & + \\
& IV & $1 \mathrm{~h}$ & - \\
V & $2 \mathrm{~h}$ & + \\
& VI & $2 \mathrm{~h}$ & - \\
& I & - & + \\
& II & - & - \\
Chicken meat loaf & III & $1 \mathrm{~h}$ & + \\
& V & $2 \mathrm{~h}$ & - \\
& VI & $2 \mathrm{~h}$ & + \\
\hline
\end{tabular}

Tab. 2. Composition of meat loaf dough

\begin{tabular}{|l|c|c|}
\hline \multicolumn{1}{|c|}{ Ingredients } & Beef meat loaf & Chicken meat loaf \\
\hline Beef rib meat & $460 \mathrm{~g}$ & - \\
\hline Cattle forearm & $460 \mathrm{~g}$ & - \\
\hline Chicken breast meat (skinned) & - & $438 \mathrm{~g}$ \\
\hline Chicken thigh meat (skinned) & - & $438 \mathrm{~g}$ \\
\hline Bovine oil & $48 \mathrm{~g}$ & $96 \mathrm{~g}$ \\
\hline Ice & $280 \mathrm{~g}$ & $280 \mathrm{~g}$ \\
\hline Dry bread & $106 \mathrm{~g}$ & $106 \mathrm{~g}$ \\
\hline Milk powder & $38 \mathrm{~g}$ & $38 \mathrm{~g}$ \\
\hline Salt & $19 \mathrm{~g}$ & $19 \mathrm{~g}$ \\
Chopped onions & $48 \mathrm{~g}$ & $48 \mathrm{~g}$ \\
\hline Black pepper & $2.5 \mathrm{~g}$ & $2.5 \mathrm{~g}$ \\
\hline Cumin & $1.2 \mathrm{~g}$ & $1.2 \mathrm{~g}$ \\
\hline Allspice & $0.6 \mathrm{~g}$ & $0.6 \mathrm{~g}$ \\
\hline Sodium nitrite & $0.1 \mathrm{~g}$ & $0.1 \mathrm{~g}$ \\
\hline
\end{tabular}

a mixer (Stomacher Lab. Blender 400), with serial dilutions up to $10^{-7}$ and $1 \mathrm{ml}$ dilutions were transferred to petri dishes. After media [Plate Count Agar (PCA, Oxoid CM325), Violet Red Bile Agar (VRBA, Oxoid CM0978), Mannitol Salt Agar (MSA, Oxoid CM0085) and Potato Dextrose Agar (PDA, Oxoid CM0139)] addition, these were incubated at $30^{\circ} \mathrm{C}$ for $48 \mathrm{~h}$ for total mesophilic aerobic bacteria (TMAB), $30^{\circ} \mathrm{C}$ for $24 \mathrm{~h}$ for Enterobacteriaceae, $37^{\circ} \mathrm{C}$ for $36 \mathrm{~h}$ for Micrococcus-Staphylococcus and $22^{\circ} \mathrm{C}$ for 5 days for yeast and moulds. At the end of the incubation period, the colonies were calculated in petri plates as previously reported $(7,22)$.

Sensory analysis. The samples were evaluated by a panel group (four males and three females aged 24-35) for colour, flavour, appearance and texture. The samples were presented in white plates to the panel in the sensory evaluation room with good lighting. In the sensory evaluation, a hedonic type scale with the highest score of 10 representing the liked features, and the lowest score of 1 denoting disliked features was used (47). 
Statistical analysis. The one-way ANOVA test was used after the SPSS Statistics 21.0 package programme for determining normal distribution in the data. Significant differences were then determined by introducing the Duncan Test (46).

\section{Results and discussion}

The yield of beef and chicken meat loaves increased by $0.69 \%$ and $1.85 \%$, respectively, with an overall yield increase of $1.27 \%$ for experimental production groups with carrageenan applied (II, IV and VI) compared with the control groups (I, III and V). The yield increase and cutting properties of the groups (IV and VI) involving tumbling and carrageenan addition are better than

Tab. 3. Yield and cutting features of beef and chicken meat loaf samples

\begin{tabular}{|c|c|c|c|c|c|c|c|}
\hline \multirow[b]{2}{*}{ Group } & \multirow[b]{2}{*}{ Application } & \multicolumn{3}{|c|}{ Beef meat $1^{\text {st }}$ and $2^{\text {nd }}$ production } & \multicolumn{3}{|c|}{ Chicken meat $1^{\text {st }}$ and $2^{\text {nd }}$ production } \\
\hline & & $\begin{array}{l}\text { Cut } \\
\text { (B/G) }\end{array}$ & $\begin{array}{c}\text { Yie } \\
(\% \text { Mean } \pm \text { SE })\end{array}$ & $\begin{array}{l}\text { Cut } \\
\text { (B/G) }\end{array}$ & $\begin{array}{l}\text { Cut } \\
\text { (B/G) }\end{array}$ & $\begin{array}{c}\text { Yie } \\
(\% \text { Mean } \pm \text { SE })\end{array}$ & $\begin{array}{l}\text { Cut } \\
\text { (B/G) }\end{array}$ \\
\hline I & $\mathrm{T}(-), \mathrm{C}(-)$ & B & $98.06 \pm 0.73$ & B & B & $96.91 \pm 0.83^{a b}$ & B \\
\hline II & $\mathrm{T}(-), \mathrm{C}(+)$ & B & $98.88 \pm 0.65$ & G & G & $99.10 \pm 0.25^{a b}$ & B \\
\hline III & T 1, C (-) & G & $98.46 \pm 0.71$ & G & G & $96.24 \pm 1.51^{b}$ & B \\
\hline IV & T 1, C (+) & G & $98.79 \pm 0.85$ & G & G & $99.25 \pm 0.49^{a}$ & G \\
\hline V & T 2, C (-) & G & $98.27 \pm 0.43$ & B & G & $97.82 \pm 0.46^{a b}$ & G \\
\hline VI & T 2, C (+) & G & $99.19 \pm 0.46$ & G & G & $98.17 \pm 0.45^{a b}$ & G \\
\hline
\end{tabular}

Explanations: Yie - \% yield; Cut - cuttability; B - bad; G-good; T (-) - tumbling not applied; T (+) - tumbling applied; T1 - tumbling applied for $1 \mathrm{~h}$; T2 - tumbling applied for $2 \mathrm{~h}$; $\mathrm{C}(-)$ - carrageenan not applied; $\mathrm{C}(+)$ - carrageenan applied; SE - standart error; values within a row with different letters are significantly different $(p<0.05)$

Tab. 4. \% Cooking loss for beef and chicken meat loaf samples (\% Mean $\pm \mathrm{SE})$

\begin{tabular}{|l|c|c|c|c|c|c|}
\hline \multicolumn{1}{|c|}{ Group } & I & II & III & IV & V & VI \\
\hline Beef meat loaf & $11.87 \pm 3.47^{\mathrm{x}}$ & $4.6 \pm 1.3^{\mathrm{y}}$ & $7.28 \pm 2.25^{\mathrm{xy}}$ & $3.92 \pm 0.03^{\mathrm{y}}$ & $7.91 \pm 1.04^{\mathrm{xy}}$ & $4.18 \pm 0.06^{\mathrm{y}}$ \\
Chicken meat loaf & $10.19 \pm 1.91^{\mathrm{a}}$ & $5.43 \pm 1.21^{\mathrm{bc}}$ & $10.91 \pm 0.42^{\mathrm{a}}$ & $3.71 \pm 0.38^{\mathrm{c}}$ & $8.88 \pm 0.91^{\mathrm{ab}}$ & $5.15 \pm 2.92^{\mathrm{bc}}$ \\
\hline
\end{tabular}

Explanations: SE - standart error; values within a row with different letters are significantly different $(\mathrm{p}<0.05)$

Tab. 5. Physicochemical parameters of meat loaves (Mean $\pm \mathrm{SE}$ )

\begin{tabular}{|l|c|l|c|c|c|c|c|c|}
\hline & Group & Application & $\mathrm{a}_{\mathrm{w}}$ & $\mathrm{pH}$ & DM (\%) & Ash (\%) & Salt (\%) & Fat (\%) \\
\hline & I & T (-), C (-) & $0.938 \pm 0.005$ & $6.26 \pm 0.12$ & $31.52 \pm 1.00$ & $2.30 \pm 0.26$ & $0.988 \pm 0.15$ & $4.64 \pm 0.21$ \\
& II & T (-), C (+) & $0.935 \pm 0.005$ & $6.33 \pm 0.83$ & $29.66 \pm 1.27$ & $2.50 \pm 0.35$ & $1.07 \pm 0.16$ & $4.60 \pm 0.14$ \\
& III & T 1, C (-) & $0.935 \pm 0.005$ & $6.28 \pm 0.10$ & $30.65 \pm 1.00$ & $2.23 \pm 0.36$ & $1.03 \pm 0.12$ & $5.10 \pm 0.99$ \\
& IV & T 1, C (+) & $0.933 \pm 0.008$ & $6.33 \pm 0.06$ & $30.53 \pm 1.28$ & $2.40 \pm 0.21$ & $1.10 \pm 0.14$ & $5.03 \pm 0.30$ \\
& V & T 2, C (-) & $0.936 \pm 0.006$ & $6.24 \pm 0.03$ & $30.28 \pm 1.88$ & $2.15 \pm 0.33$ & $0.99 \pm 0.11$ & $4.73 \pm 0.19$ \\
& VI & T 2, C (+) & $0.935 \pm 0.01$ & $6.33 \pm 0.04$ & $29.40 \pm 1.56$ & $2.30 \pm 0.19$ & $1.01 \pm 0.15$ & $4.82 \pm 0.14$ \\
& I & T (-), C (-) & $0.927 \pm 0.005$ & $6.26 \pm 0.12$ & $35.80 \pm 1.52$ & $2.18 \pm 0.22$ & $1.23 \pm 0.10$ & $7.38 \pm 0.12$ \\
& II & T (-), C (+) & $0.933 \pm 0.006$ & $6.34 \pm 0.08$ & $33.87 \pm 0.96$ & $1.79 \pm 0.63$ & $1.13 \pm 0.10$ & $7.65 \pm 0.29$ \\
\cline { 2 - 7 } Chicken meat loaf & III & T 1, C (-) & $0.928 \pm 0.003$ & $6.23 \pm 0.16$ & $35.25 \pm 1.47$ & $2.12 \pm 0.27$ & $1.19 \pm 0.10$ & $7.72 \pm 0.41$ \\
& IV & T 1, C (+) & $0.922 \pm 0.005$ & $6.31 \pm 0.11$ & $36.14 \pm 3.43$ & $2.35 \pm 0.22$ & $1.20 \pm 0.84$ & $8.01 \pm 0.15$ \\
& V & T 2, C (-) & $0.923 \pm 0.005$ & $6.27 \pm 0.11$ & $35.76 \pm 2.39$ & $2.15 \pm 0.21$ & $1.19 \pm 0.08$ & $8.02 \pm 0.21$ \\
& VI & T 2, C (+) & $0.924 \pm 0.005$ & $6.31 \pm 0.10$ & $35.99 \pm 1.89$ & $2.01 \pm 0.21$ & $1.15 \pm 0.11$ & $7.69 \pm 0.18$ \\
\hline
\end{tabular}

Explanations: DM - dry matter; T (-) - tumbling not applied; T (+) - tumbling applied; T1 - tumbling applied for 1 h; T2 - tumbling applied for $2 \mathrm{~h}$; $\mathrm{C}(-)$ - carrageenan not applied; C $(+)$ - carrageenan applied
Data for physicochemical parameters including $\mathrm{pH}$, aw, dry matter, salt, ash and fat content for all storage durations are presented in Table 5.

Yeast-mould growth was absent during storage of the beef meat and chicken meat loaves for all samples. The TMAB, Micrococcus-Staphylococcus and Enterobacteriaceae concentrations range from 3.76 to $4.56 \log _{10} \mathrm{CFU} / \mathrm{g}$, 3.11 to $3.95 \log _{10} \mathrm{CFU} / \mathrm{g}$ and 0.65 to $1.5 \log _{10} \mathrm{CFU} / \mathrm{g}$ on the $1^{\text {st }}$ day and 4.55 to $5.25 \log _{10} \mathrm{CFU} / \mathrm{g}, 2.98$ to $3.88 \log _{10}$ $\mathrm{CFU} / \mathrm{g}$ and 1.68 to $1.81 \log _{10} \mathrm{CFU} / \mathrm{g}$ on the $15^{\text {th }}$ day, respectively, for beef meat loaves. Chicken meat loaves yielded corresponding values of 3.85-4.4 $\log _{10}$ $\mathrm{CFU} / \mathrm{g}, 2.91-3.63 \log _{10}$ $\mathrm{CFU} / \mathrm{g}$ and $0-1.10 \log _{10}$ $\mathrm{CFU} / \mathrm{g}$ on the $1^{\text {st }}$ day and 3.12-3.75 $\log _{10} \mathrm{CFU} / \mathrm{g}$, 2.30-2.65 $\log _{10} \mathrm{CFU} / \mathrm{g}$ and $0-1.02 \log _{10} \mathrm{CFU} / \mathrm{g}$ on the $15^{\text {th }}$ day of storage. The average values for 


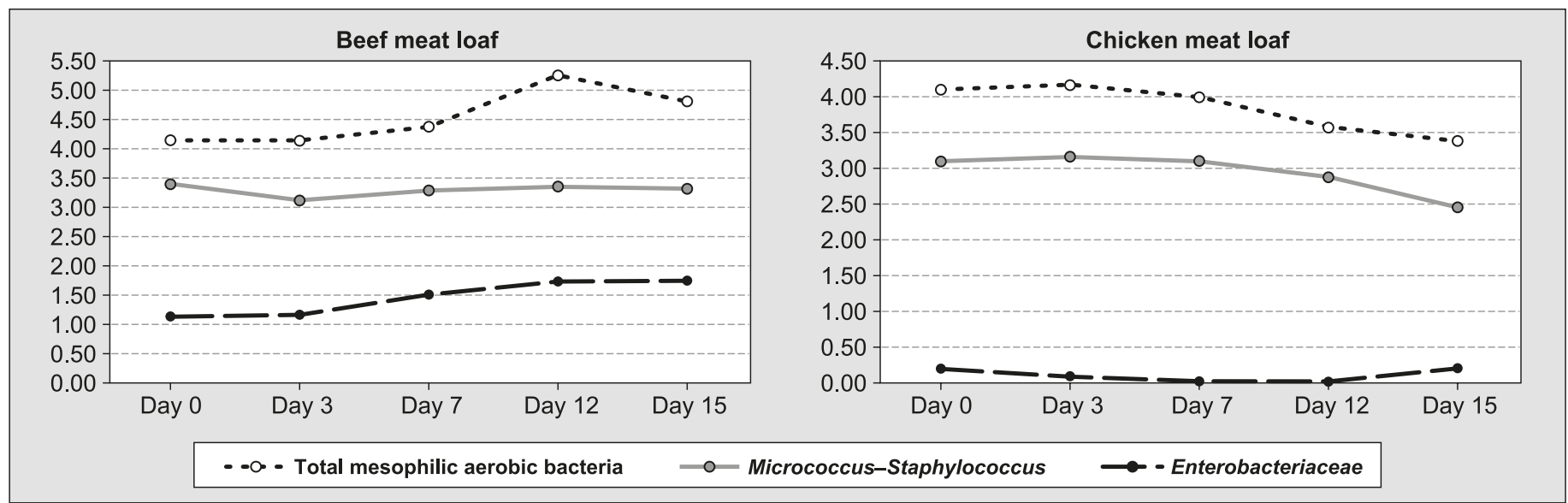

Fig. 1. Microbiological values of meat loaves during storage $\left(\log _{10} \mathrm{CFU} / \mathrm{g}\right)$

the microbial counts during storage $\left(0^{\text {th }}, 3^{\text {rd }}, 7^{\text {th }}, 12^{\text {th }}\right.$ and $15^{\text {th }}$ days) are also displayed in Figure 1.

For both meat types, groups (IV and VI) that $1^{\text {st }}$ group of beef meat loaves and the $1^{\text {st }}$ and $3^{\text {rd }}$ groups of chicken meat loaves. The effect of carrageenan addition on the cooking loss is evident $\left(2^{\text {nd }}, 1^{\text {st }}\right.$ and involved tumbling and carrageenan application are rated higher by the panellists. Although the carrageenan application (for both meat types) produced a higher score, the difference between the groups was not statistically significant $(\mathrm{p}>0.05)$. The sensory evaluation scores for loaves subjected to tumbling surpassed those for meat groups without tumbling ( $\mathrm{p}<0.05$, Tab. 6 and 7).

The increased yield of all groups treated with carrageenan $(1 \%)$ compared with control groups is attributed to improved water retention capacity associated with carrageenan. Data on the optimum effect and additives use levels are lacking, with variations observed according to the raw material, produced food, other additives, carrageenan type, composition and concentration. However, the use of $2 \%$ kappa-carrageenan is reported to positively affect the yield and textural properties of meatballs with low-fat content (23) and increase the water retention capacity of sausages (32) and the water retention capacity characteristics of salt present in food (38).

The highest cooking loss values are displayed by the

Tab. 6. Sensory analysis results of beef meat loaves

\begin{tabular}{|c|l|c|c|c|c|}
\hline Group & \multicolumn{1}{|c|}{ Application } & Flavor & Texture & Appaerance & Colour \\
\hline I & T (-), C (-) & $7.07 \pm 0.30^{\mathrm{c}}$ & $7.21 \pm 0.26^{\mathrm{c}}$ & $8.14 \pm 0.31^{\mathrm{ab}}$ & $7.85 \pm 0.40^{\mathrm{b}}$ \\
II & T (-), C (+) & $7.85 \pm 0.27^{\mathrm{bc}}$ & $7.85 \pm 0.27^{\mathrm{bc}}$ & $8.07 \pm 0.28^{\mathrm{b}}$ & $8.78 \pm 0.29^{\mathrm{a}}$ \\
III & T 1, C (-) & $7.64 \pm 0.32^{\mathrm{c}}$ & $8.28 \pm 0.32^{\mathrm{ab}}$ & $8.14 \pm 0.31^{\mathrm{ab}}$ & $8.50 \pm 0.31^{\mathrm{ab}}$ \\
IV & T 1, C (+) & $8.85 \pm 0.27^{\mathrm{a}}$ & $8.78 \pm 0.21^{\mathrm{a}}$ & $8.78 \pm 0.23^{\mathrm{ab}}$ & $9.07 \pm 0.19^{\mathrm{a}}$ \\
V V & T 2, C (-) & $7.85 \pm 0.31^{\mathrm{bc}}$ & $8.71 \pm 0.28^{\mathrm{a}}$ & $8.71 \pm 0.22^{\mathrm{ab}}$ & $9.00 \pm 0.27^{\mathrm{a}}$ \\
VI & T 2, C (+) & $8.71 \pm 0.28^{\mathrm{ab}}$ & $9.00 \pm 0.25^{\mathrm{a}}$ & $8.92 \pm 0.19^{\mathrm{a}}$ & $9.28 \pm 0.22^{\mathrm{a}}$ \\
& Average of Applications & & & & \\
& T (-) & $7.46 \pm 0.21^{\mathrm{b}}$ & $7.53 \pm 0.19^{\mathrm{b}}$ & $8.10 \pm 0.20^{\mathrm{b}}$ & $8.32 \pm 0.26^{\mathrm{b}}$ \\
& T (1) & $8.25 \pm 0.23^{\mathrm{a}}$ & $8.53 \pm 0.19^{\mathrm{a}}$ & $8.46 \pm 0.20^{\mathrm{ab}}$ & $8.78 \pm 0.18^{\mathrm{ab}}$ \\
& T (2) & $8.28 \pm 0.22^{\mathrm{a}}$ & $8.85 \pm 0.19^{\mathrm{a}}$ & $8.82 \pm 0.14^{\mathrm{a}}$ & $9.14 \pm 0.17^{\mathrm{a}}$ \\
& C (-) & $7.52 \pm 0.18$ & $8.07 \pm 0.19$ & $8.33 \pm 0.16$ & $8.32 \pm 0.26$ \\
& C (+) & $8.47 \pm 0.17$ & $8.54 \pm 0.16$ & $8.59 \pm 0.20$ & $8.78 \pm 0.14$ \\
\hline
\end{tabular}

Explanations: differences between groups with different letters in the same column are important $(\mathrm{p}<0.05)$; $\mathrm{T}(-)$ - tumbling not applied; T $(+)$ - tumbling applied; T1 - tumbling applied for $1 \mathrm{~h}$; T2 - tumbling applied for $2 \mathrm{~h} ; \mathrm{C}(-)$ - carrageenan not applied; $\mathrm{C}(+)$ - carrageenan applied

Tab. 7. Sensory analysis results of chicken meat loaves

\begin{tabular}{|l|l|c|c|c|c|}
\hline Group & \multicolumn{1}{|c|}{ Application } & Flavor & Texture & Appaerance & Colour \\
\hline I & T (-), C (-) & $7.28 \pm 0.26^{\mathrm{c}}$ & $7.71 \pm 0.26^{\mathrm{c}}$ & $8.28 \pm 0.22^{\mathrm{b}}$ & $8.92 \pm 0.24^{\mathrm{b}}$ \\
II & T (-), C (+) & $7.71 \pm 0.35^{\mathrm{bc}}$ & $7.92 \pm 0.19^{\mathrm{bc}}$ & $8.64 \pm 0.28^{\mathrm{ab}}$ & $9.21 \pm 0.18^{\mathrm{b}}$ \\
III & T 1, C (-) & $7.85 \pm 0.31^{\mathrm{bc}}$ & $8.14 \pm 0.27^{\mathrm{bc}}$ & $8.71 \pm 0.28^{\mathrm{ab}}$ & $9.00 \pm 0.18^{\mathrm{b}}$ \\
IV & T 1, C (+) & $8.57 \pm 0.29^{\mathrm{ab}}$ & $8.78 \pm 0.23^{\mathrm{a}}$ & $9.14 \pm 0.17^{\mathrm{a}}$ & $9.57 \pm 0.17^{\mathrm{a}}$ \\
V & T 2, C (-) & $8.42 \pm 0.22^{\mathrm{ab}}$ & $8.64 \pm 0.22^{\mathrm{ab}}$ & $8.85 \pm 0.23^{\mathrm{ab}}$ & $9.57 \pm 0.17^{\mathrm{a}}$ \\
VI & T 2, C (+) & $8.92 \pm 0.30^{\mathrm{a}}$ & $9.07 \pm 0.19^{\mathrm{a}}$ & $9.21 \pm 0.23^{\mathrm{a}}$ & $9.64 \pm 0.13^{\mathrm{a}}$ \\
& Average of Applications & & & & \\
& T (-) & $7.50 \pm 0.22^{\mathrm{b}}$ & $7.82 \pm 0.16^{\mathrm{b}}$ & $8.46 \pm 0.18^{\mathrm{b}}$ & $9.07 \pm 0.15^{\mathrm{b}}$ \\
& T (1) & $8.21 \pm 0.22^{\mathrm{a}}$ & $8.46 \pm 0.18^{\mathrm{a}}$ & $8.92 \pm 0.17^{\mathrm{ab}}$ & $9.28 \pm 0.13^{\mathrm{ab}}$ \\
& T (2) & $8.67 \pm 0.19^{\mathrm{a}}$ & $8.85 \pm 0.15^{\mathrm{a}}$ & $9.03 \pm 0.16^{\mathrm{a}}$ & $9.60 \pm 0.10^{\mathrm{a}}$ \\
& C (-) & $7.85 \pm 0.16$ & $8.16 \pm 0.15$ & $8.61 \pm 0.14$ & $9.16 \pm 0.12$ \\
& C (+) & $8.40 \pm 0.19$ & $8.59 \pm 0.14$ & $9.00 \pm 0.14$ & $9.47 \pm 0.09$ \\
\hline
\end{tabular}

Explanations: as in Tab. 6. 
control groups), with significant reductions in some produced groups. Generally, the lowest cooking losses are obtained in the $4^{\text {th }}$ groups produced after tumbling for $1 \mathrm{~h}$ and carrageenan treatment. Comparing the effects of carrageenan and tumbling on cooking loss, carrageenan is assigned a more significant influence by increasing the water retention capacity of the product. This is because the cooking loss depends on the ability of the protein matrix to immobilise fat and water. However, non-meat components, particularly in lowfat meat doughs, are important for the gelling ability, water retention capacity and storage stability (34). The tumbling process imposes thermal energy to muscle fibres, with the physical effects of falling, crashing and friction on the muscle proteins. Myofibrillar proteins, for example, transform to a soluble form because of the heat generated by the thermal energy in the tissue $(21,30)$. Combining the water retention properties of carrageenan and the tumbling effect on proteins, the heat generated during these processes is considered to catalyse the water binding effect. In fact, Trius and Sebranek (49) stated that the water binding effect of carrageenan particles in meat products occurs during heat treatment, with the bond converted to gel during the cooling process.

In this study, the $6^{\text {th }}$ groups of beef and chicken meat exposed to $2 \mathrm{~h}$ tumbling and carrageenan show higher cooking loss values compared with their corresponding $4^{\text {th }}$ groups. This is probably due to mechanical damage from the tumbling process over time. Moreover, reduced water retention capacity of the proteins with increasing heat is another possible explanation. This highlights dominance of changes occurring in the protein fractions from tumbling over water retention capacity from carrageenan. Schmidt (42) stated that the kinetic energy produced by the tumbling process loosens the sarcomere structure, causing rapid disintegration of actin filaments and $Z$ discs. Demirok et al. (16) reported that the use of tumbling and phosphate influences the moisture amount, water-soluble protein and $\alpha$-amino groups in cooked döner. Although no application affected the sarcoplasmic and myofibrillary proteins, proteolysis resulted from heat treatment.

For cooking loss, the effect of tumbling is higher in beef meat and decreases as the loss decreases. This is probably because the protein content of a beef loaf surpasses that of a chicken loaf, since thigh and breast meat served as raw materials. We infer that cooking loss in these loaf samples can be reduced by increasing the breast composition and thus the total protein percentage.

The mechanical properties of meat, particularly connective tissue protein, are affected by collagen. The texture is influenced by the collagen amount and solubility with heat treatment. The heat-induced changes in muscle components depend on temperature and time, whereas the hardening or softening of meat depends on the cooking conditions (21). Since the inter-group heat treatment and time mechanisms are identical, observed differences in the cutting properties are assigned to changes in the protein properties and water retention capabilities. The cutting properties of the $4^{\text {th }}$ and $6^{\text {th }}$ groups, processed by tumbling and carrageenan application support this assertion. A protein film is formed around the meat fibres-muscle fibres from extraction of myofibrillar proteins by the tumbling process. Thus, the increased brittleness and juiciness of the product also affects the cutting properties $(20,55)$, whereas carrageenan also increases the water retention properties. However, Modi et al. (37) stated that different amounts of carrageenan added to the composition of meatballs produced experimentally positively affect the water retention, cooking loss and hardness properties of the products. Similarly, Lin and Mei (33) reported that the addition of $0.41 \mathrm{~g} / 100 \mathrm{~g}$ iota carrageenan to meat dough compositions increased the emulsion stability and water retention capacity. These researchers attributed this to the formation of a more stable complex of fat-in-water emulsion by denaturing of meat proteins during the heat treatment. Aktaş and Gençcelep (2) observed that the increase in emulsion viscosity enhanced its stability, and the decrease in cooking loss is associated with the emulsion stability.

The differences in the chemical properties of the meat loaves are influenced by many factors (e.g. type of raw material, size of meat loaf, temperature and heat treatment duration, type of tumbler machine and additives). In this study, the similarity of the basic factors affecting the chemical properties of the meat loaves for all groups likely accounts for the absence of significant differences for the analysed parameters. McIvor et al. (35) reported moisture, fat, ash and protein in chicken meat loaf of $52.6 \%, 17.10 \%, 3.50 \%$ and $22.81 \%$, respectively. Uebersax et al. (51) reported moisture contents of $73.6 \%, 73.2 \%, 73 \%$ and $72.6 \%$ fat content of $0.36 \%, 1.59 \%, 2.80 \%$ and $4.53 \%$, and $\mathrm{pH}$ values of 5.74, 5.77, 5.81 and 5.86 for turkey meat loaves mechanically deboned at $0 \%, 10 \%, 20 \%$ and $30 \%$ levels, respectively. Also, Acton and Dick (1) observed that the moisture, fat, protein and ash for turkey meat loaves prepared by adding $20 \%$ skin are $65.7 \%$, $10.8 \%, 20.7 \%$ and $2.0 \%$, respectively. Furthermore, Sen and Karim (43) concluded that the $\mathrm{pH}$ of a product increases with increasing meat piece sizes for restructured sheep meat. Similarly, Gurikar et al. (21) reported that the $\mathrm{pH}$ of a product increases with increasing meat piece size for restructured pork. Gurikar et al. (21) and Vasanthi et al. (53) further suggest that increasing $\mathrm{pH}$ values are linked to losses in free acid groups with rising heat treatment time. Sharedeh et al. (44) indicated that a small pilot tumbling device is suitable for static salting, whereas large tumblers were suitable for combining massage and salting. Villalobos-Delgado et al. (54) noted that tumbling is effective only for stickiness of dry-cured lamb leg samples produced from different tumbling times after salting. Mocanu et al. (36) found 
higher levels of dry matter and ash in meat loaf samples produced from pork back fat and different vegetable oils compared with the control group.

In this study, yeast-mould growth is undetected in the meat loaf samples; the concentrations of TMAB, Micrococcus-Staphylococcus and Enterobacteriaceae range from 2.90 to $6.05 \log _{10} \mathrm{CFU} / \mathrm{g}, 2.00$ to $4.27 \log _{10}$ $\mathrm{CFU} / \mathrm{g}$ and 0 to $3.62 \log _{10} \mathrm{CFU} / \mathrm{g}$, respectively. These findings are consistent with Devatkal et al. (17) who reported aerobic plaques concentrations on buffalo meat loaf stored at $4^{\circ} \mathrm{C}$ of $2.27,3.10,3.94,5.13$ and $6.38 \log _{10} \mathrm{CFU} / \mathrm{g}$ levels for the $1^{\text {st }}, 5^{\text {th }}, 10^{\text {th }}, 15^{\text {th }}$ and $20^{\text {th }}$ days of storage, respectively. These researchers suggested that the microorganisms may be due to contamination from manual contact during packaging, storage and sampling for analysis after heat treatment. Carroll et al. (13) found that the approximate number of TMAB in turkey meat loaves treated with different marinated combinations was $2 \log _{10} \mathrm{CFU} / \mathrm{cm}^{2}$ on the $0^{\text {th }}, 1^{\text {st }}, 5^{\text {th }}$ and $10^{\text {th }}$ days of storage, $3 \log _{10} \mathrm{CFU} / \mathrm{cm}^{2}$ on the $14^{\text {th }}$ day, $4 \log _{10} \mathrm{CFU} / \mathrm{cm}^{2}$ on the $20^{\text {th }}$ day and $5.5 \log _{10} \mathrm{CFU} / \mathrm{cm}^{2}$ on the $70^{\text {th }}$ day. In microbiological analyses conducted after the cooking process, McIvor et al. (35) attributed the absence of coliform bacteria, yeast-mould, Salmonella spp. and $S$. aureus growth and the low-level aerobic colony number of $8 \times 10^{2} \mathrm{CFU} / \mathrm{g}$ to the efficacy of the heating process. The preference of layer hens associated with high contamination levels and trimming meat residues in this study makes microbiological controls compulsory (27). Although heat treatment is applied during the production phase, avoiding contamination during storage is vital. Chow (15) indicated that the presence of a routine heat treatment step in producing different meat loaves prevents the development of pathogenic microorganisms in the meat loaves from meat with expected high contamination level.

For the $1^{\text {st }}$ day of storage, the TMAB, MicrococcusStaphylococcus and Enterobacteriaceae loads for both meat loaves are similar. The average TMAB and Enterobacteriaceae loads of the beef loaves, however, increased in the final days of storage. In contrast, TMAB, Micrococcus-Staphylococcus and Enterobacteriaceae average values decreased for chicken meat loaves. This is possibly because the average $\mathrm{a}_{\mathrm{w}}$ in the chicken loaves are relatively low and the salt ratios are higher. The increase in salt in the compositions of the foods also decreases the $\mathrm{a}_{\mathrm{w}}$. This factor, which is considered as the water binding property of salt, also accounts for the salt-induced antimicrobial effect $(3,11)$. Similarly, many studies $(28,31,52)$ suggest that the gradual decrease of $\mathrm{a}_{\mathrm{w}}$ and increasing salt content for different meat products are due to bacterial inhibition and/or their synergetic effects.

Considering the averages of the applications for both meat types for sensory analyses, it is important for the carrageenan addition and tumbling process to produce higher sensory scores. Bharti et al. (9) suggested that
45 min tumbling for small chicken pieces marinated in spices and yoghurt increases the physicochemical and sensory quality characteristics of the products. Hullberg et al. (24) indicated that the tumbling process produces better texture and more uniform cured meat colour for smoked meat. They further stated that tumbling reduced the undesirable pores, and no difference was noted in sensory preferences, but many panellists preferred meat samples processed without tumbling. Modi et al. (37) suggested that added carrageenan groups are more favourable than the control group, whereas Prabhu and Monge (41) concluded the effect of carrageenan use on the hardness, stickiness, chewability and slicing characteristics of turkey breast meat was significant. Also, Mohan and Singh (38) reported that the beef steaks using $0.5 \%$ kappa-carrageenan yield better sensory results for colour, hardness, juiciness and overall acceptability. Furthermore, Chareonthaikij et al. (14) stated that the use of $0.3 \%$ transglutaminase and 1\% kappa-carrageenan improved the sensory and textural properties in fish meatballs.

This study revealed that effective data were to prepare appropriate formulations for the consumers like their sensory properties, by enhancing the textural properties and quality of meat loaves constituting problems in production technology. For cooking loss, the least loss was observed in Group 4 for beef and chicken meat loaves, which were treated with carrageenan and processed by tumbling for $1 \mathrm{~h}$. The tumbling process and carrageenan used in the meat industry exhibit positive effects on the technological improvement of the meat loaf.

\section{References}

1. Acton J. C., Dick R. L.: Effect of skin content on some properties of poultry meat loaves. Poult. Sci. 1978, 57, 1255-1259, doi: 10.3382/ps.0571255.

2. Aktaş N., Gençcelep H.: Effect of starch type and its modifications on physicochemical properties of bologna-type sausage produced with sheep tail fat. Meat Sci. 2006, 74, 2, 404-408, doi: 10.1016/j.meatsci.2006.04.012.

3. Albarracin W., Sanchez I. C., Grau R., Barat J. M.: Salt in food processing; usage and reduction: a review. Int. J. Food Sci. Technol. 2011, 46, 1329-1336, doi: 10.1111/j.1365-2621.2010.02492.x.

4. Alejandre M., Poyato C., Ansorena D., Astiasarán I.: Linseed oil gelled emulsion: A successful fat replacer in dry fermented sausages. Meat Sci. 2016, 121, 107-113, doi: 10.1016/j.meatsci.2016.05.010.

5.Anandh M. A., Radha K., Venkatachalapathy R. T., Lakshmanan V.: Quality and acceptability of restructured buffalo meat rolls in refrigerated storage. World J. Dairy Food Sci. 2011, 6, 207-211.

6. AOAC.: Official Methods of Analysis. Association of Official Analytical Chemists. $14^{\text {th }}$ ed. USA Association of Official Analytical Chemists Inc, Arlington, Virginia 1984

7. APHA, Marshall R. (ed.): Standard Methods for the Examination of Dairy Products. $16^{\text {th }}$ ed. American Public Health Association Press, Washington DC 1992.

8. Atashkar M., Hojjatoleslamy M., Boroujeni L. S.: The influence of fat substitution with $\kappa$-carrageenan, konjac, and tragacanth on the textural properties of low-fat sausage. Food Sci. Nutr. 2018, 1-8, doi: 10.1002/fsn3.620.

9. Bharti S. K., Anita B., Das S. K., Biswas S.: Effect of vacuum tumbling time on physico-chemical, microbiological and sensory properties of chicken tikka. J. Stored Prod. Postharvest Res. 2011, 2, 7, 139-147.

10. Bhaskar Reddy G. V., Mandal P. K., Sen A. R., Reddy K. S.: Developments in science, technology, quality and constraints of restructured meat products a review. Int. J. Meat Sci. 2015, 5, 1, 14-48, doi: 10.3923/ijmeat.2015.14.48.

11. Blesa E., Aliño M., Barat J. M., Grau R., Toldrá F., Pagán M. J.: Microbiology and physico-chemical changes of dry-cured ham during the post-salting stage 
as affected by partial replacement of $\mathrm{NaCl}$ by other salts. Meat Sci. 2008, 78, 135-142, doi: 10.1016/j.meatsci.2007.07.008.

12. Candogan K., Kolsarici N.: The effects of carrageenan and pectin on some quality characteristics of low-fat beef frankfurters. Meat Sci. 2003, 64, 2 , 199-206, doi: 10.1016/S0309-1740(02)00181-X.

13. Carroll C. D., Alvarado C. Z., Brashears M. M., Thompson L. D., Boyce J. Marination of turkey breast fillets to control the growth of Listeria monocytogenes and improve meat quality in deli loaves. Poult. Sci. 2007, 86, 1, 150-155, doi: 10.1093/ps/86.1.150.

14. Chareonthaikij P., Srilarp J., Winnavoravej N., Uan-On T., Torrico D., Phitchayaphon $C$.: Effects of transglutaminase and kappa-carrageenan on the physical and sensory qualities of fish (Pangasianodon hypophthalmus) patties. Current J. Appl. Sci. Technol. 2018, 18, 1, 12-23.

15. Chow M. (ed.): Easy Meat Loaf Cookbook The Effortless Chef Series $1^{\text {st }}$ ed. vol. XXXI, CreateSpace Independent Publishing Platform Saxonberg Associates, New Jersey 2015, p. 14-90

16. Demirok E., Kolsarıcı N., Akoğlu I. T., Özden E.: The effects of tumbling and sodium tripolyphosphate on the proteins of döner. Meat Sci. 2011, 89, 154-159, doi: 10.1016/j.meatsci.2011.04.008.

17. Devatkal S., Mendiratta S. K., Kondaiah N.: Quality characteristics of loaves from buffalo meat, liver and vegetables. Meat Sci. 2004, 67, 3, 377-383, doi: 10.1016/j.meatsci.2003.11.006.

18. Dutra M. P., Cardoso G. P., Ramos E. M., Ramos A. D. L. S., Pinheiro A. C. M. Fontes $P$. R.: Technological and sensory quality of restructured low-fat cooked ham containing liquid whey. Ciênc. Agrotec. 2012, 36, 86-92, doi: 10.1590/ S1413-70542012000100011.

19. Ensor S. A., Mandigo R. W., Calkins C. R., Quint L. N.: Comparative evaluation of whey protein concentrate, soy protein isolate and calcium-reduced nonfat dry milk as binders in an emulsion-type sausage. J. Food Sci. 1987, 52, 5, 1155-1158, doi: 10.1111/j.1365-2621.1987.tb14032.x.

20. Feiner G.: Phosphates, Salts (Sodium Chloride and Potassium Chloride, Citrate, Lactate) and Hydrocolloids, [in:] Feiner G. (ed.): Meat Products Handbook, Practical Science and Technology. Woodhead Publishing Limited, Sawston, $1^{\text {st }}$ ed. Cambridge 2006, p. 72-88.

21. Gurikar A. M., Lakshmanan V., Gadekar Y. P., Sharma B. D., Anjaneyulu A. S.: Effect of meat chunk size, massaging time and cooking time on quality of restructured pork blocks. J. Food Sci. Technol. 2014, 51, 7, 1363-1369, doi: 10.1007/s13197-012-0644-9.

22. Harrigan W. F., McCance M. F.: Laboratory Methods, [in:] Harrigan W. F., McCance M. F. (ed.): Food and Dairy Microbiology. Academic Press, Abb. London-New York-San Francisco 1976

23. Hsu S. Y., Chung H. Y.: Effects of $\kappa$-carrageenan, salt, phosphates and fat on qualities of low fat emulsified meatballs. J. Food Eng. 2001, 47, 2, 115-121, doi: 10.1016/S0260-8774(00)00106-0.

24. Hullberg A., Johansson L., Lundström K.: Effect of tumbling and RN genotype on sensory perception of cured-smoked pork loin. Meat Sci. 2005, 69, 721-732, doi: 10.1016/j.meatsci.2004.07.013.

25. Hullberg A., Lundström K.: The effects of RN genotype and tumbling on processing yield in cured-smoked pork loins. Meat Sci. 2004, 67, 409-419, doi: 10.1016/j.meatsci.2003.11.015.

26. Irshad A., Sharma B. D., Ahmed S. R., Talukder S., Malav O. P., Kumar A. Effect of incorporation of calcium lactate on physico-chemical, textural, and sensory properties of restructured buffalo meat loaves. Vet. World. 2016, 9 , 2, 151-159, doi: 10.14202/vetworld.2016.151-15.

27. Jayathilakan K., Sultana K., Radhakrishna K., Bawa A. S.: Utilization of byproducts and waste materials from meat, poultry and fish processing industries: a review. J. Food Sci. Technol. 2012, 49, 3, 278-293, doi: 10.1007/ s13197-011-0290-7.

28. Kamisaki-Horikoshi N., Sameshima T., Omori Y., Fuchu H., Miake K. Morioka Y., Kotani K., Kosai K., Goto S., Watanabe I., Nakashima Y. Inoguchi Y., Nishizaka K., Igimi S., Shinmura Y., Hattori A.: Effects of water activity and sodium lactate on the growth of Listeria monocytogenes in raw ham. J. Jpn. Soc. Food Sci. Technol. 2013, 60, 7, 347-356, doi: 10.3136/ nskkk.60.347.

29. Koutsopoulos D. A., Koutsimanis G. E., Bloukas J. G.: Effect of carrageenan level and packaging during ripening on processing and quality characteristics of low-fat fermented sausages produced with olive oil. Meat Sci. 2008, 79, 188-197, doi: 10.1016/j.meatsci.2007.08.016

30. Krause J. R., Ockerman H. W., Krol B., Moerman P. C., Plimpton Jr R. F. Influence of tumbling, tumbling time, trim and sodium tripolyphosphate on quality and yield of cured hams. J. Food Sci. 1978, 43, 853-855, doi: 10.1111/j.1365-2621.1978.tb02438.x

31. Laranjo M., Agulheiro-Santos A. C., Potes M. E., Cabrita M. J., Garcia R. Fraqueza M. J., Elias M.: Effects of genotype, salt content and calibre on quality of traditional dry-fermented sausages. Food Cont. 2015, 56, 119-127, doi: 10.1016/j.foodcont.2015.03.018
32. Lin K., Ketton J.: Textural and physicochemical properties of low-fat, precooked ground beef patties containing carrageenan and sodium alginate J. Food Sci. 1998, 63, 571-574, doi: 10.1111/j.1365-2621.1998.tb15787.x.

33. Lin K. W. Mei M. Y.: Influences of gums, soy protein isolate, and heating temperatures on reduced-fat meat batters in a model system. J. Food Sci. 2000, 65, 1, 48-52, doi: 10.1111/j.1365-2621.2000.tb15954.x.

34. Marchetti L., Andres S. C., Califano A. N.: Low-fat meat sausages with fish oil: Optimization of milk proteins and carrageenan contents using response surface methodology. Meat Sci. 2014, 96, 1297-1303, doi:10.1016/j.meatsci. 2013.11.004

35. McIvor D., Baccus-Taylor G. S. H., Comissiong E. A.: Manufacture of spent hen ayami and its utilisation in meatloaf and fresh sausage. British Poult. Sci. 2002, 43, 218-222, doi: 10.1080/00071660120121427.

36. Mocanu G. D., Barbu M., Nistor O. V., Andronoiu D. G., Botez E.: The effect of the partial substitution of pork back fat with vegetable oils and walnuts on the chemical composition, texture profile and sensorial properties of meatloaf. Food Technol. 2015, 39, 1, 58-69.

37. Modi V. K., Yashoda K. P., Naveen S. K.: Effect of carrageenan and oat flour on quality characteristics of meat kofta. Int. J. Food Prop. 2009, 12, 228-242, doi: 10.1080/10942910802252155.

38. Mohan A., Singh R. K.: Functional properties of carrageenan on color stability and sensory characteristics of beef steaks. Food Biosci. 2016, 15, 72-80, doi: 10.1016/j.fbio.2016.05.006.

39. Pearson A. M., Tauber F. W.: Sausage Formulations, [in:] Pearson A. M., Tauber F. W. (ed.): Processed Meats. $2^{\text {nd }}$ ed. The AVI Publishing Company Inc, Westport, Connecticut 1984, p. 211-250.

40. Pietrasik Z., Shand P. J.: Effect of blade tenderization and tumbling time on the processing charcteristics and tenderness of injected cooked roast beef Meat Sci. 2004, 66, 871-879, doi: 10.1016/j.meatsci.2003.08.009.

41. Prabhu G., Monge J. C.: Use of semi-refined carrageenan as a water binder in deli turkey breast. Meat and Muscle Biology 2016, 1, 2, 37-38.

42. Schmidt G. R.: Sectioned and Formed Meat, [in:] Proc. $31^{\text {st }}$ Ann. Recip. Meat Conf. Amer. Meat Sci. Ass., Storrs, Connecticut 1978, p. 18-24.

43. Sen A. R., Karim S. A.: Effect of meat particle size on quality attributes of restructured mutton steaks. J. Food Sci. Technol. 2003, 40, 423-425.

44. Sharedeh D., Mirade P. S., Venien A., Daudin J. D.: Analysis of salt penetration enhancement in meat tissue by mechanical treatment using a tumbling simulator. J. Food Eng. 2015, 166, 377-383, doi: 10.1016/j.jfoodeng.2015.06.023.

45. Sharma H., Sharma B. D., Mendiratta S. K., Talukder S., Ramasamy G.: Efficacy of flaxseed flour as bind enhancing agent on the quality of extended restructured mutton chops. AJAS. 2014, 27, 247-255, doi: 10.5713/ ajas.2013.13319

46. Steel R. G. D., Torrie J. H. (ed.): Principles and Procedures of Statistics. $2^{\text {nd }}$ ed. Mc Graw-Hill International Book Company, Tokyo 1981

47. Stone H., Sidel J. L. (ed.): Sensory Evaluation Practices (Food science and technology). $3^{\text {rd }}$ ed. Academic Press Inc, London 2004.

48. Talukder S., Sharma B. D., Mendiratta S. K., Malav O. P., Sharma H. Gokulakrishnan P.: Development and evaluation of extended restructured chicken meat block incorporated with colocasia (Colocasia esculenta) flour. J. Food Process. Technol. 2013, 4, 2, 207, doi: 10.4172/2157-7110.1000207.

49. Trius A., Sebranek J. G.: Carrageenans and their use in meat products. Crit. Rev. Food Sci. Nutr. 1996, 36, 1\&2, 69-85, doi: 10.1080/10408399609527719.

50. TSE.: Turkish Standardization Institute. Turkish Standard, TS 1746, Meat and Meat Products Total Ash Determination. 2001, Accepted Date: 15.02.2001.

51. Uebersax M. A., Dawson L. E., Uebersax K. L.: Physical and chemical composition of meat loaves containing mechanically debonned turkey meat. Poult. Sci. 1978, 57, 660-669, doi: 10.3382/ps.0570660.

52. Uğuz Ş., Soyer A., Dalmış $\ddot{U}$.: Effects of different salt contents on some quality characteristics during processing of dry-cured Turkish pastirma. J. Food Qual. 2011, 34, 204-211, doi: 10.1111/j.1745-4557.2011.00382.x.

53. Vasanthi C., Venkataramanujam V., Dushyanthan K.: Effect of cooking temperature and time on the physico-chemical, histological and sensory properties of female carabeef (buffalo) meat. Meat Sci. 2007, 76, 2, 274-280, doi: 10.1016/j.meatsci.2006.11.018.

54. Villalobos-Delgado L. H., Caro I., Blanco C., Prieto N., Moran L., Prieto N., Bodas R., Giráldez F. J., Mateo J.: Quality characteristics of a dry-cured lamb leg as affected by tumbling after dry-salting and processing time. Meat Sci. 2014, 97, 115-122, doi: 10.1016/j.meatsci.2014.01.015.

55. Yetim H., Gökalp H. Y.: Meat technology tumbling and massaging. General principles, techniques and pre-operations. Food. 1988, 13, 6, 431-437.

56. Zayas J. F., Lin C. S.: Quality characteristics of frankfurters containing corn germ protein. J. Food Sci. 1988, 53, 6, 1587-1591, doi: 10.1111/j.1365-2621. 1988.tb07791.x

Corresponding author: Nihat Telli PhD, Department of Food Technology, Vocational School of Technical Sciences, Konya Technical University, Konya, Turkey; e-mail: ntelli@ktun.edu.tr 